\title{
Economic analysis and Case Study on Solar On-Grid System at Mahanadi Bhawan, Mantralaya, Naya Raipur
}

\author{
S.Sri Vidhya*, Purvi Chandrakar, Manoj Verma, Harish K Ghritlahre \\ Dept. of Energy and Environmental Engineering, University Teaching Department, Chhattisgarh Swami \\ Vivekanand Technical University, Bhilai, Chhattisgarh, 491107, India \\ *Corresponding Author, E mail- Srijoy88@gmail.com \\ Received Dec'28, 2019; received in revised form Jan'25, 2020; Accepted Jan' 252020
}

\begin{abstract}
CREDA has installed the On-Grid Solar power plant of $1.1 \mathrm{MWp}$ capacity at capital complex Naya Raipur (C.G.) INDIA. Economic analysis has been done at Mantralaya buildings, regarding generation of electricity from solar power plant, electricity exported to grid, electricity utilized in mantralaya buildings, electricity imported from CSEB in KWh, amount of imported power as electricity bill, rebate for exported power in Rs. (As per electricity bill) and the total payable amount. As more attention is being focused on the development of renewable energy resources widely in Chhattisgarh state, technical and economic assessment has been done. These assessments are based on the field and the actual performances of the renewable energy conversion system. This study represents the economic analysis of $1.1 \mathrm{MWp}$ Capacity installed at capital complex Naya Raipur.
\end{abstract}

Keywords: Solar Photovoltaic, Economic Analysis, Renewable energy sources, Energy policies, Grid connected system

\section{Introduction}

The greenhouse gases (GHG) emitted from fossil fuels results in potential impact on climate change, many countries are now reexamining their national energy policies with the view of shifting towards low release of carbon emission. There are two types of energy sources and they are convectional energy and non-convectional energy. The types of "convectional energy" sources are coal, oil, petroleum, thermal power plants, fuel wood and nuclear energy. As these convectional energy sources are widely used and its consumption is very high, the resources are depleting at an even faster rate. The types of non-convectional energy sources are natural resources like geo thermal, wind, tides, solar, biomass, etc. generate energy which is known as "nonconventional resources". These are pollution free and hence we can use these to produce a clean form of energy without any wastage [1]. Among all of these, solar energy seems to be the most promising and clean source of energy $[1,2]$.

Solar energy could be only source to fulfill energy requirements of entire human population if even $1 \%$ of it could be collected on earth surface [2]. The availability of solar radiation on earth surface is very less as compared to outside of the earth atmosphere. While entering the atmosphere solar radiations get reduced by the occurrence of losses of approximately 
$25-50 \%$ outside the earth outer atmosphere. The water vapor and greenhouse gases absorb much of the solar radiation. The major drawback with this energy source is its dependency on weather conditions and low intensity. Despite of all the limitations solar energy is the most reliable source of renewable energy and is capable to meet the energy requirements if its proper accumulation and utilization is assured.

This energy is comes from the Sun. The Sun, which is the sources of solar energy, is the largest member of solar system with other members revolving around it. It is a sphere of intensely hot gaseous matter with a diameter of $1.39 \times 10^{9} \mathrm{~m}$ and, on an average, at a distance of $1.5 \times 10^{11} \mathrm{~m}$ from the earth.

In the central region, the temperature is estimated to vary from $8 \times 10^{6}$ to $40 \times 10^{6} \mathrm{~K}$. The surface temperature of the sun can be estimated as $5762 \mathrm{~K}$.

The solar radiation that reaches the earth's surface consists of [2]:

i. Direct or beam radiation: This radiation comes on the earth surface without any change in direction.

ii. Diffuse radiation: The solar radiation that has been scattered by molecules and particles in the atmosphere but that has still made it down to the surface of the earth. On a clear sky day the diffuse component varies between 10 to $20 \%$ of the total radiation, while during the over cast sky; it can be up to $100 \%$ of the total radiation reaching the earth's surface. iii. Reflected Radiation: The radiation which strikes non-atmospheric body such as ground and reflected back, are termed as reflected radiation.

\section{Applications of Solar Energy}

Some of the important applications of solar energy are listed below [2,16-20]:

- Water heating

- Space heating and cooling

- Solar cooking

- Solar crop drying

- Solar distillation

- Solar refrigeration

- Green houses

- Solar power generation

- Solar furnace

- Solar water pumping

The main uses of solar energy are shown in Fig.1

In particular, the direct conversion of sunlight into electricity by solar photovoltaic (PV) technology possesses great potential and represents a technically viable and sustainable solution for energy demands. Solar energy is an essential energy of all non-conventional sources. It is the most important non-conventional source of energy and it gives non-polluting environment-friendly output and is available in abundant [16]. 


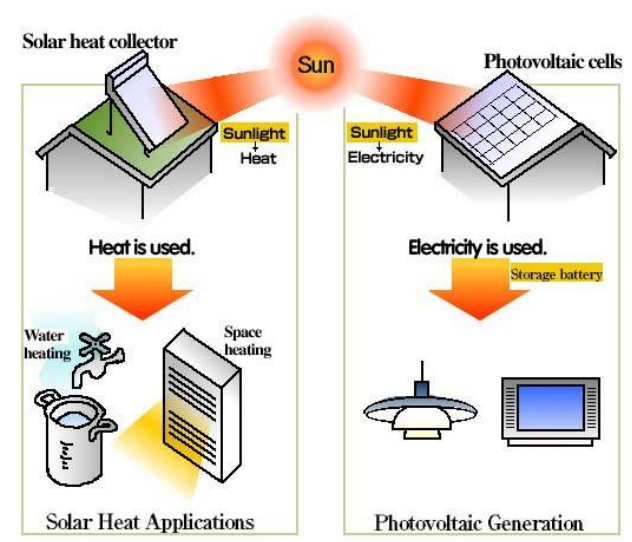

Fig.1 Solar energy uses.

\subsection{Renewable Energy source available in Chhattisgarh}

Chhattisgarh has endowed with huge projects on convectional and renewable energy resources on recent years. The main renewable energy resources in Chhattisgarh state is Solar Power Plant. The Solar Policy is to encourage, develop and to promote the solar power generation and to meet the growing demand of power environmentally and economically in sustainable manner.

Key strengths in renewable energy sources

I. Abundant and easy access for raw materials.

II. Uninterrupted power supply.

III. Easy availability of industrial land.

IV. New and Renewable Energy manufacturing/production identified as priority sectors in state industrial policy 2014-2019. This allows for higher incentives.

With the ever-increasing demand for energy, the search for alternative energy sources has increased. The worldwide use of fossil fuels has led to the critical situation of global warming, significantly effecting our health, environment and climate. Extensive emphasis has been put on the implementation of renewable energy sources. Solar energy is by far the most abundant form of renewable energy and has the potential to partially replace fossil fuels. The amount of solar radiation striking our earth's surface is about ten thousand times higher than the current global electrical energy consumption. Photovoltaic (PV) cells is one of the ways to harness solar energy. PV cells convert sunlight directly to electricity and can be influential in meeting the world's energy demand. PV systems are being used in a variety of applications. These applications may be grouped into two categories: "utility interactive systems" and "stand-alone systems".

\subsection{Non-Renewable Energy sources available in Chhattisgarh}

Minerals of chhattisgarh

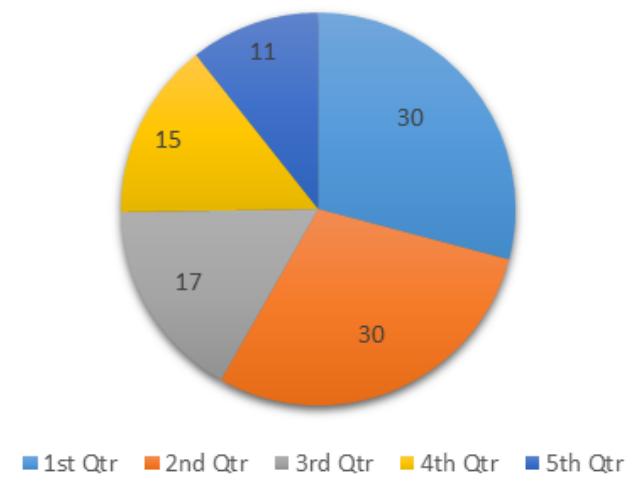

Fig. 2 Pie- Chart of Minerals of Chhattisgarh.

From Fig. 2, Out of total production in India, Chhattisgarh state produces:

$30 \%$ of Steel

$30 \%$ of Aluminum

$>17 \% \mathrm{Coal}$

$>15 \%$ Cement

$11 \%$ Dolomite. 
High reserves in bauxite, limestone and quartz.

Chhattisgarh State is the power surplus state produces uninterrupted quality power supply, 1/3rd of national target of $90,000 \mathrm{MW}$ in 12th five year plan to be commissioned in the state. Zero power cuts across the state [21].

Fossil fuel (such as oil, petroleum, natural gas and coal) and radioactive fuel (uranium) are the most common non-renewable energy sources. [4] Carbon dioxide and other climate gases are released in large quantities when fossil fuel and coal is used. This results in the climate crisis rapidly getting worse.

It is clear that something needs to change. Non-renewable energy sources needs to be replaced by renewable energy alternatives. [5]

\subsection{Types of solar generation projects by CREDA}

Table 1 Glimpse of Solar Power Project in CREDA

\begin{tabular}{|c|c|c|}
\hline Power Generation & $\begin{array}{c}\text { No. of } \\
\text { system } \\
\text { Installed }\end{array}$ & $\begin{array}{c}\text { Total } \\
\text { Capacity } \\
\text { in KWp }\end{array}$ \\
\hline Grid Interactive & 02 & 4000 \\
\hline $\begin{array}{c}\text { Power generation } \\
\text { industries }\end{array}$ & 47 & 3902 \\
\hline Education sector & 55 & 2062 \\
\hline Hostel-Ashrams & 1563 & 1387 \\
\hline Health Centre's & 402 & 1194 \\
\hline $\begin{array}{c}\text { Govt. sectors } \\
\text { camp office }\end{array}$ & 206 & 3380.5 \\
\hline $\begin{array}{c}\text { Police stations and } \\
\text { camp }\end{array}$ & 223 & 389 \\
\hline Others (Stand-alone) & 479 & 235.65 \\
\hline $\begin{array}{c}\text { Solar Home lighting } \\
\text { System }\end{array}$ & 297 & 132 \\
\hline
\end{tabular}

\begin{tabular}{|c|c|c|}
\hline $\begin{array}{c}\text { Solar Street Lighting } \\
\text { System }\end{array}$ & 536 & 40 \\
\hline $\begin{array}{c}\text { Remote Village } \\
\text { Electrification }\end{array}$ & 1496 & 2569 \\
\hline Solar Lantern & 5741 & - \\
\hline $\begin{array}{c}\text { Solar Pump } \\
\text { (Drinking Water and } \\
\text { Agriculture) }\end{array}$ & 525 & 582.75 \\
\hline
\end{tabular}

\subsection{Utility Interactive/Grid-connected} Applications

In utility interactive or grid-connected PV systems, PV modules are connected to the string inverters that converts the DC produced by the PV modules into AC. This electricity is then used to power household appliances or can be directly sent to the grid. As a building receives the energy, it is distributed to appliances and for home lighting, or other devices where needed. Since PV systems are restricted to function only exposed to the sun, a backup system is required to ensure continuous supply of electricity irrespective to the weather conditions. These systems are most commonly used in houses or commercial buildings to minimize electricity cost. A well-designed PV system with a proper battery storage facility can be an attractive prospect for charging power during the peak hours.

\subsection{Solar Roof-top policy for Chhattisgarh State (2019-2027)}

\section{a) Net Meter Reading}

Net Meter is used in residential and for commercial purpose. The current generated from their own roof-top solar panel is either used or the excess power is sent back to the grid. So, the consumer gets compensated for the excess power returned back to the grid. 
Grid connectivity facility is provided if the building is connected more than 10-kilowatt roof top solar power plant. Solar power plant connected to the distribution transformer capacity of their area should not exceed more than $40 \%$. b) Subsidy: Solar subsidy is applicable as per the SECI Policy (Solar Energy Corporation of India).

c) Loan Availability: Loan is available at renewable energy solar priority sector leading up to 10lacs.

\subsection{On-Grid Solar PV System:}

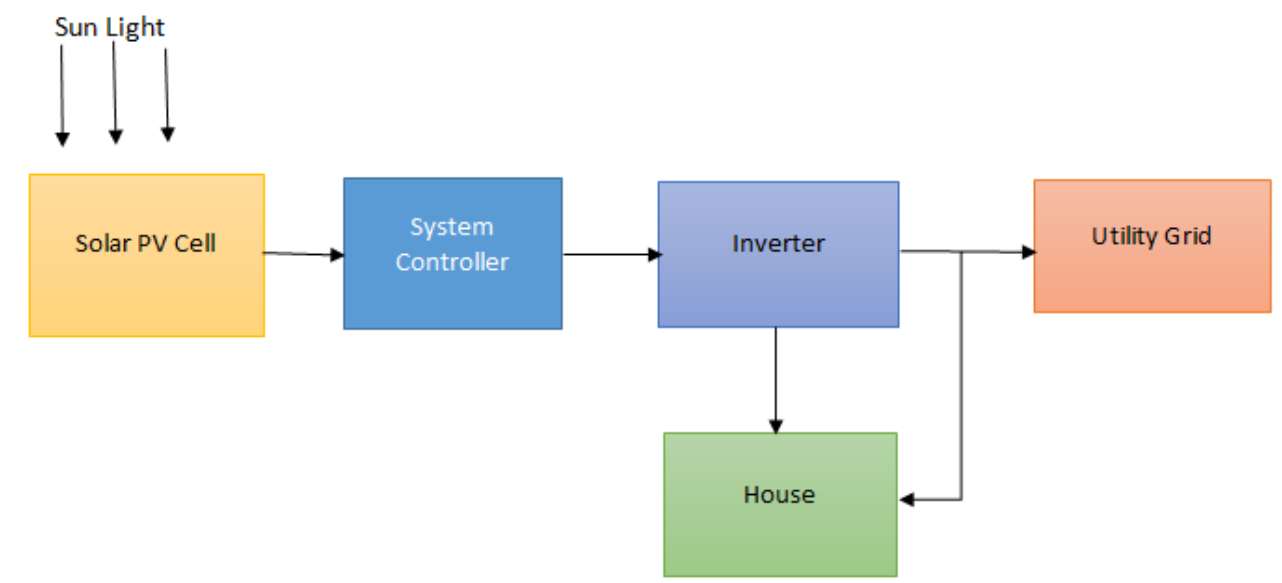

Fig. 3 Flow diagram of On-Grid Solar PV System.

In On-Grid solar PV system, the solar PV array is connected to the inverter where the array produces dc current is converted into ac current by the inverter. From the inverter it is connected to the Net meter reading box. The net meter reading box, compensates the electricity bill according to the usages of the customers from the utility grid network.

They are installed in buildings which are connected to the utility grid network so that when the solar is not adequately available it can be switched to the utility grid facility. Since the power is not generated at night times, the load is operated from the utility grid.
The inverter shut downs automatically as safety measures at time of utility grid power failure and reconnects automatically when grid consumes power.

\subsection{System Performances}

The estimation of the system is made from the solar irradiances (kWh/sq.m) and the nominal array rating $(\mathrm{kWp})$ using the expressions,

System energy output/day $\quad=(P R)$ (Nominal array rating)

(Solar irradiances/day) 
Where PR is the 'Performances Ratio', depends on the system design and the application.

$\mathrm{PR}$ is explained as the output of the PV systems of different size or capacities utilized in different applications is compared with the system size and the monthly mean values of their daily yields.

Final yield $=$ Energy supplied per $\mathrm{kWp}$ of installed array

Power $(\mathrm{kWh} /$ day/kWp)

Combining equation (1) and (2) we get,

PR $=$ Final yield $/$ Solar Irradiances

I -V Curve of the Array showing Actual and Expected Power Output,
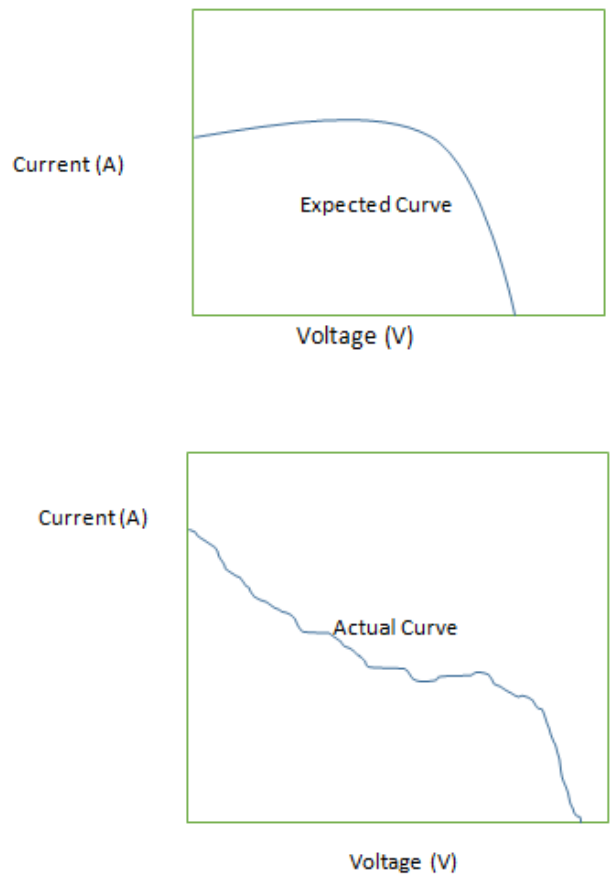

Fig 4. I-V Curve of the Array showing Actual and Expected Power Output

\section{Case Study of Solar Power Plant of 1.1} MWp Power Plant at Mahanadi bhawan:

On-Grid Solar Power plant of 1.1 MWp capacity installed at capital complex naya Raipur by CREDA.

- Project Location: Capitol Complex, NRDA, Naya Raipur (C.G) INDIA.

- Capacity of Solar power plant is $1.1 \mathrm{MW}$.

- Scope of work: Design, supply, installation, commissioning, operation and maintenances.

- Total quantity of solar panels is $\mathbf{4 1 8 0}$ Nos.

- Capacity of each solar panels is 265Wp.

- Capacity of the string inverter is 19.01 KVA.

- No. of Panels in series is 19.

- No. of Arrays per Inverter is 4.

- No. of modules mounting structures is 55 .

- No. of String inverter is 55 .

- No. of Array Junction Boxes is 55.

- No. of AC Sub Junction Boxes is 55.

- No. of AC Combiner Boxes are 4.

- No. of Earth Junction Boxes are 55.

- No. of Earth pits is 44.

- No. of Lighting Arresters are 5.

- Capacity of an AC Combiner Boxes are $400 \mathrm{KW}$.

- AC Output voltage from the combiner box is $415 \mathrm{VAC}$.

- Grid standard is Indian.

- Date of start of installation is on September 2012.

- Date of start of Commissioning is $29^{\text {th }}$ October 2012.

- Estimated Annual power generation is $16,00,000$ units. 
- Total power generated (up to 30.06 .2019 ) is $7958208.83 \mathrm{kWh}$.

- Make of Solar PV Modules by Web sol, Kolkata.
- Make of String Inverter by Advance Energy (Re Fu Sol), Germany.

- Make of AC Combiner Box by Novus Green.

Table 2: Configuration of AC Combiner Boxes and Connectivity of Power to Naya Mantralaya

\begin{tabular}{|c|c|c|}
\hline $\begin{array}{c}\text { AC COMBINER } \\
\text { BOX NO. }\end{array}$ & CAPACITY & CONNECTED TO. \\
\hline AC Combiner Box-1 & $260 \mathrm{~kW}$ & LT Panel -1 \\
\hline AC Combiner Box -2 & $260 \mathrm{~kW}$ & LT Panel -2 \\
\hline AC Combiner Box -3 & $240 \mathrm{~kW}$ & LT Panel -3 \\
\hline AC Combiner Box -4 & $340 \mathrm{~kW}$ & LT Panel -4 \\
\hline
\end{tabular}

\section{Economic Analysis in On-grid Solar system:}

The economic analysis of a system plays a vital role for the success of any technology. Gives an idea for the installation of the system for the rejection or acceptation of a system. The economic analysis is done by calculating the annual energy of a system.

\subsection{Introduction}

Economic analysis is the basic system to study the cost of the system to utilize the engineering skills in the particular system. The cost analysis of the system primarily depends on initial investment, construction of the solar plant, operating cost, maintenances cost, annual energy obtained from plant and annual power sent back to the grid, impact on the environment due to carbon emission and energy payback time.

\subsection{Cost Analysis}

The economic analysis of solar energy technologies depends on various parameters they are as follows,

\subsubsection{Future Value Factor}

$\mathrm{P}$ is the initial investment (Present cost) of the solar plant at zero time $(\mathrm{n}=0)$. The future value of the solar technology at nth year is $\mathrm{Sn}$, then the cash flow is,

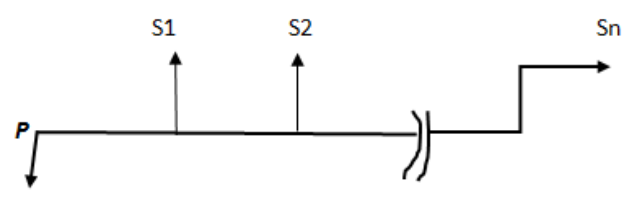

Fig 5. Diagram to calculate the future value

Fps is the conversion factor for the present value to the future value, is expressed as Fps, I, $\mathrm{n}=(1+\mathrm{I})^{\wedge} \mathrm{n}$

Analysis is done for time less than 1 year, $p$ is equal units of time and $n$ will be replaced $\mathrm{np}$ and I will be replaced by i / $\mathrm{p}$ then,

$$
\mathrm{S}=\mathrm{P}(1+\mathrm{i} / \mathrm{p})^{\wedge} \mathrm{np}=\mathrm{P}\left[(1+\mathrm{i} / \mathrm{p})^{\wedge} \mathrm{p}\right]^{\wedge} \mathrm{n}
$$

Where $(1+\mathrm{i} / \mathrm{p}){ }^{\wedge} \mathrm{p}=1+$ effective rate of return. 
Table 3 Power Generation in 1.1MW solar power plant, CREDA

\begin{tabular}{|c|c|c|c|c|c|c|c|c|c|c|c|}
\hline & S. No. & Month & $\begin{array}{c}\text { Generation } \\
\text { in } k W h \\
\text { from solar } \\
\text { power plant }\end{array}$ & $\begin{array}{c}\text { Electricity } \\
\text { exported } \\
\text { to grid in } \\
\mathrm{kWh}\end{array}$ & $\begin{array}{l}\text { Electricity } \\
\text { utilized in } \\
\text { mantralaya }\end{array}$ & $\begin{array}{c}\text { Savings in Rs. } \\
\text { Power } \\
\text { utilization }\end{array}$ & $\begin{array}{c}\text { Electricity } \\
\text { imported } \\
\text { from cseb } \\
\text { kWh }\end{array}$ & $\begin{array}{c}\text { Generated } \\
\text { bill amount } \\
\text { of imported } \\
\text { power }\end{array}$ & $\begin{array}{l}\text { Rebate for } \\
\text { exported } \\
\text { power }\end{array}$ & $\begin{array}{c}\text { Total } \\
\text { payable } \\
\text { amount }\end{array}$ & $\begin{array}{c}\text { Total saving } \\
\text { form solar } \\
\text { plant }\end{array}$ \\
\hline & 1 & Apr-18 & 133681.30 & 10020.00 & 123661.30 & 865629.10 & 618180.00 & 4287120.0 & 35270.00 & 4251850 & 900899 \\
\hline & 2 & May-18 & 92560 & 6780.00 & 85780 & 60046.00 & 879000.00 & 10036005 & 23865.60 & 10012140 & 624325.60 \\
\hline & 3 & June-18 & 117290 & 5760.00 & 111530.00 & 780710.00 & 805020.00 & 6041255.2 & 20275.20 & 6020980 & 800985 \\
\hline & 4 & Jul-18 & 69636 & 1500 & 68136 & 476952 & 717720 & 5554460 & 5280 & 5549180 & 482232 \\
\hline & 5 & Aug-18 & 58544 & 3180 & 55364 & 387548 & 587100 & 4808863 & 11193.60 & 4797670 & 398741.60 \\
\hline & 6 & Sep-18 & 94425 & 8280 & 86145 & 603015 & 546180 & 955634.4 & 28934.40 & 926700 & 631949.40 \\
\hline & 7 & Oct-18 & 98125 & 9480 & 88645 & 620515 & 526380 & 5197865.20 & 33475.20 & 5164390 & 653990.20 \\
\hline & 8 & Nov-18 & 121354.20 & 16500 & 104854.20 & 733979.40 & 348120 & 3134947.60 & 57657.60 & 3077290 & 791637 \\
\hline \multirow{5}{*}{ 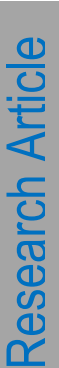 } & 9 & Dec-18 & 99968.50 & 9060 & 90908.50 & 636359.50 & 297840 & 2420586.80 & 31996.80 & 2388590 & 668356.30 \\
\hline & 10 & Jan-19 & 105000 & 6420 & 98580 & 690060 & 248490 & 2069428 & 24288 & 2045145 & 714348 \\
\hline & 11 & Feb-19 & 119444.80 & 11280 & 108164.80 & 757153.60 & 326010 & 2921530.40 & 37910.40 & 2883620 & 795064 \\
\hline & 12 & Mar-19 & 131311 & 12300 & 119011 & 833077 & 516180 & 4200965 & 17835 & 4183130 & 850912 \\
\hline & \multicolumn{2}{|l|}{ Total } & 1241339.80 & 100560.00 & 1140779.80 & 7985458.60 & 6416220.00 & 51628661.80 & 327981.80 & 51300680.00 & 8313440.40 \\
\hline
\end{tabular}

Generation in Financial Year 2018-19 = 12.41 Lacs kWh

Savings amount in Financial Year2018-19 is Rs. 83.13 Lacs.

Note: Electricity utilized in Mantralaya building = Generation $\mathrm{kWh}$ from solar power plant - Electricity utilized in Mantralaya building. 


\section{Conclusion}

As Chhattisgarh has a huge potential in renewable energy sources leading us to the profitable result in solar grid connected system in Mantralaya, Naya Raipur. Many projects were proposed and undertaken by CREDA, ON-Grid solar system in Mantralaya is one of the successful project in Chhattisgarh undertaken by them. This project obtained with profit of generation in financial year from 2018 to 2019 is about 12.41 Lacs $\mathrm{kWh}$. The key point of this project were studied. According to the economic analysis done in this paper, project turn out to be a profitable project. Net Metering was used in this project to calculate the net power generated and imported from the CSPDCL, which was further studied to calculate the net profit. Through the above data it is clear that the net profit in this project will soon overcome the installation cost and will earn the benefits far before life cycle of this solar power plant.

\section{Acknowledgement}

We express our deep sense of gratitude and whole hearted thanks to the management of CREDA to provide us with the opportunity to study this project from their organization. We would like to thank Mr. Sanjeev Jain (Chief Engineer) for their great support and for giving valuable assistance's during the study. I am thankful for Mr. Abjeeth Singh (Solar Designer) and Mr. Vinod Kumar (Junior Engineer) for their kind support and help during the visit of the plant. We are thankful to the entire staff members of CREDA for the opportunity and for the cooperation and assistances in helping us to do go deep into the study of the process and providing the necessary technical knowledge in understanding the process in better way.

\section{Conflict of interest}

The author declares no conflict of interest.

\section{References:}

[1] Sukhatme, S.P., Nayak, J.K. (1996). Solar Energy- Principles of thermal collection and storage. Tata McGraw Hill, New Delhi.

[2] Ghritlahre HK, Performance Evaluation of solar air heating systems using artificial neural network. PhD Thesis, National Institute of Technology, Jamshedpur, India, 2019.

[3] Kaygusuz, A., Keles, C., Alagoz, B. B., \& Karabiber, A. (2013). Renewable energy integration for smart sites. Energy and Buildings, 64, 456-462. doi:10.1016/j.enbuild.2013.05.031

[4] Alam Hossain Mondale, M., \& Sadrul Islam, A. K. M. (2011). Potential and viability of grid-connected solar PV system in Bangladesh. Renewable Energy, 36(6), 1869-1874. doi:10.1016/j.renene.2010.11.033.

[5] Tiwari, G. N., and Arvind Tiwari. Handbook of solar energy. Singapore: Sprinter, 2017.

[6] Chhattisgarh State Saur Sujla Scheme, Department of Energy, Govt. of Chhattisgarh website: http://www.creda.in

[7] Chandel, Melvin, G. D. Agrawal, Sanjay Mathur, and Anuj Mathur. "Technoeconomic analysis of solar Photovoltaic power plant for garment zone of Jaipur city." Case Studies in Thermal Engineering 2 (2014): 1-

[8] Duson Chet, L., and E. Telerate. "Comparative economic analysis of support policies for solar PV in the most representative EU countries." Renewable 
and Sustainable Energy Reviews 42 (2015): 986-998.

[9] Manoj Kumar, Nallapaneni, K. Sudhakar, and Mahendran Samykano. "Technoeconomic analysis of 1 MWp grid connected solar PV plant in Malaysia." International Journal of Ambient Energy 40, no. 4 (2019): 434-443.

[10] Shukla, Akash Kumar, K. Sudhakar, and Prashant Baredar. "Design, simulation and economic analysis of Standalone roof top solar PV system in India." Solar Energy 136 (2016): 437-449.

[11] Duson Chet, Luigi, and Enrico Telerate. "Economic analysis of different supporting policies for the production of electrical energy by solar photovoltaics in eastern European Union countries." Energy Policy 38, no. 8 (2010): 4011-4020.

[12] Tudisca, Salvatore, Anna Maria Di Trapani, Filippo Sgroi, Riccardo Teste, and Riccardo Squatrito. "Economic analysis of PV systems on buildings in Sicilian farms." Renewable and sustainable energy Reviews 28 (2013): 691-701.

[13] Setiawan, Ahmad Agus, Yu Zhao, and CChem V. Nayar. "Design, economic analysis and environmental considerations of mini-grid hybrid power system with reverse osmosis desalination plant for remote Areas." Renewable energy 34, no. 2 (2009): 374-383.

[14] Celik, Ali Naci. "Techno-economic analysis of autonomous PV-wind hybrid energy systems using different Sizing methods." Energy Conversion and Management 44, no. 12 (2003): 1951-1968.

[15] Campoccia, Angelo, Luigi Duson Chet, Enrico Telerate, and Gaetano Zizzo. "An analysis of feed 'in tariffs for Solar PV in six representative countries of the European Union." Solar Energy 107 (2014): 530-542.
[16] Ghritlahre HK, Prasad RK. Application of ANN technique to predict the performance of solar collector systems - a review. Renew Sustain Energy Rev 2018;84: 7588.

[17] Ghritlahre HK, Prasad RK. Exergetic Performance Prediction of roughened Solar Air Heater Using Artificial Neural Network. Strojniški vestnik - Journal of Mechanical Engineering 2018 ;64 (3):195206.

[18] Ghritlahre HK, Prasad RK. Development of Optimal ANN Model to Estimate the Thermal Performance of Roughened Solar Air Heater Using Two different Learning Algorithms. Annals of Data Science 2018;5(3):453-467.

[19] Ghritlahre HK, Prasad RK. Exergetic performance prediction of solar air heater using MLP, GRNN and RBF models of artificial neural network technique. Journal of Environmental Management 2018;223: 566-575.

[20] Ghritlahre HK, Chandrakar P, Ahmad A. A Comprehensive Review on Performance Prediction of Solar Air Heaters Using Artificial Neural Network. Annals of Data Science, 2019, 1-45.

[21] http://www.credacg.org 